\title{
Counterfeiting in the Primary Industry Sector and the Threat to New Zealand's Economy
}

Author/s: Stephen Quirke and Rhys Ball

To cite this article: Quirke, S. \& Ball, R. (2019). Counterfeiting in the Primary Industry Sector and the Threat to New Zealand's Economy. National Security Journal, 1(1), 61-74. doi:10.36878/nsj201901.61

To link to this article: $\underline{\text { https://doi.org/10.36878/NSJ201901.61 }}$

View CrossRef data: https://search.crossref.org/?q=10.36878\%2FNSJ201901.61\# 


\title{
COUNTERFEITING IN THE PRIMARY INDUSTRY SECTOR AND THE THREAT TO NEW ZEALAND'S ECONOMY
}

\author{
Stephen Quirke and Rhys Ball ${ }^{1}$
}

\begin{abstract}
Counterfeiting in its various iterations presents a potentially significant threat to our international reputation as a premium exporter of primary products. Taking existing international scholarly research in the area of food fraud, this article presents a typology of counterfeit activity as it pertains to the New Zealand primary industry sector. Through selected case studies, we explain how counterfeiting is a far more nuanced and complex problem than generally considered, and conclude that there should be a much stronger appetite for an integrated public-private identification framework that understands these variations in order to effectively pre-empt and mitigate the impact of primary product counterfeiting in this country.
\end{abstract}

Keywords: Counterfeiting, Intellectual Property Theft, Deception, Adulteration, Tampering, Simulation, Misrepresentation, Product Fraud, Private Sector, Partnership, Primary Industry, New Zealand, Economic Motivation

\section{Introduction}

...International Organization for Standardization (ISO) defines a counterfeit as a "material good imitating or copying an authentic material good." Definitions vary, but there is a distinction between trademark misuse and pure product fraud, even if counterfeiting is understood to cover both cases. ${ }^{1}$

The New Zealand primary export sector is forecast to earn NZ $\$ 46$ billion of revenue, or $80 \%$ of all merchandise exports and $11 \%$ of its Gross Domestic Product (GDP) in

$1 \quad$ Stephen Quirke is a New Zealand-based international security consultant and graduate of the Massey University Masters of International Security Programme, and has a Certificate in Horticulture (Fruit production) from the Eastern Institute of Technology (EIT). Email contact quirke.nz@gmail.com. Rhys Ball is a Lecturer at Massey University's Centre for Defence and Security Studies, and currently teaches into the Intelligence Studies programme. Email contact r.ball@massey.ac.nz 
2019. The sector is also vulnerable to counterfeiting, as well as other forms of intellectual property theft that can, if neglected, present health risks, cause economic and reputational loss, and directly affect national interests. OECD data suggested that the volume of international trade in counterfeit, pirated or illicit products was estimated to have been "as much as USD $\$ 509$ billion", or 3.3\% of world trade, in 2016. ${ }^{3}$

After a period that saw this country manage high profile counterfeit and contamination-related scandals in the food products sector, in 2012 the Ministry for Primary Industries (MPI) acknowledged that it had "no control over counterfeiting". ${ }^{4}$ Local media investigations at the time highlighted three important issues facing the dairy sector in particular; counterfeiting existed in the industry and the need for brand protection was seen as a serious concern for the dairy industry; there was no collaboration between government and industry regarding counterfeiting; and there appeared to be no government department taking ownership of counterfeiting in New Zealand or abroad. ${ }^{5}$ Although the primary industries sector is in regular contact with the MPI, the Ministry of Business, Innovation and Employment (MBIE), Ministry of Foreign Affairs and Trade (MFAT) and related organisations, there remains no explicit policy or strategy sector framework for anti-counterfeiting initiatives designed to protect New Zealand's export markets. Despite isolated prosecutions, it can be argued that New Zealand still lacks the ability to adequately forewarn, let alone systematically address, counterfeiting in the primary sector.

Being a complex area with multiple definitions, there is limited understanding of the extent of the phenomena as it applies to the New Zealand primary products industry. This article presents an analysis of counterfeiting examples within a selection of primary industry sectors - wine, kiwifruit, apple and pear, mānuka honey and dairy. We use a collective literature review, ${ }^{6}$ these selected cases, public sector commentary and industry interviews to develop a typology of counterfeiting so as to offer a starting point to better understand the complex nuances of such activity. By presenting a primary product counterfeit typology, this research will help identify further strategies that may assist in the development and implementation of a more integrated proactive set of counter-measures for industries with explicit raw material and processed product counterfeit vulnerabilities.

The World Trade Organisation (WTO) Glossary defines counterfeiting as the "unauthorised representation of a registered trademark carried on goods identical or similar to goods for which the trademark is registered, with a view to deceiving the purchaser into believing that he/she is buying the original goods." In the United States, food fraud is a "collective term that encompasses the deliberate substitution, addition, tampering, or misrepresentation of food, food ingredients, or food packaging, or false or misleading statements made about a product for economic gain." ${ }^{\text {" Moore } e t ~ a l ~ a d d ~ t h a t ~}$ further terms are often used to describe product fraud associated with food including "economic adulteration, economically motivated adulteration [EMA] and food coun- 
terfeiting." Spink acknowledges that there is no common definition of food fraud, or food product counterfeiting, because of the variety of deceptions that are used within the production and supply chain distribution of product, as well as the fact that different agencies - both regulatory and law enforcement - often place more emphasis on the intellectual property (IP) or trademark infringement component of the activity. ${ }^{10}$ In New Zealand, MBIE applies an IP-related definition, defining counterfeiting as the "manufacture of goods that bear a sign that is identical with, or similar to, a registered trademark." ${ }^{11}$ Curiously for New Zealand, since being granted investigatory and enforcement powers in 2011, MBIE has never received, nor investigated, a complaint of counterfeiting or trademark infringement. ${ }^{12}$ The term replacement is also often used to describe reports of authentic material being replaced with another less expensive, substitute without the purchaser's knowledge and for the seller's economic gain. ${ }^{13}$ Only two pieces of New Zealand legislation specifically use the term 'counterfeit product' or 'counterfeit goods' ${ }^{14}$ and neither makes any explicit reference to food-related fraud. While no food-related statutes speak of counterfeit activities, they do identify "offences involving deception" which fit with international definitions, by making specific reference to adulterating, tampering, misrepresenting, falsifying, removing, or failing to apply any and all necessary brand or material descriptions, for the purposes of "obtaining any material benefit." 15

Developing a typology provides insight into the nature of specific counterfeit actions and those who might conduct such activity. Taking existing criminology typology examples common within the crime science field, Spink et al have presented a broad typology of "product counterfeiters, counterfeiting and offender groups" (see Figure 1) in order to understand how such activity is "perceived, researched and categorized." ${ }^{16}$ 'Counterfeit' products are those where all elements of a product are fraudulently replicated, including packaging. 'Adulterated' products are those where one or more elements of the legitimate product is substituted or fraudulent. 'Tampered' describes products or packaging which are legitimate but have been used in a fraudulent way, as opposed to 'Simulated' fraud where unauthorised and/or copied product is designed to look like, but not exactly copy, the real product. 'Over-Run' products, according to Spink et al is when legitimate product is made in excess of production agreements, and 'Theft' describes actual product that is stolen and passed off as legitimately procured. The sale or distribution of legitimate goods outside of intended markets is known as 'Diversion'.

Furthering this work, the authors have concentrated on the types of counterfeiting seen within the New Zealand primary products industry, and have mapped the known examples collected for this research and current legislative frameworks and definitions, against the counterfeiting criteria proposed by Spink et al to present a typology that is able to withstand the multiple definitions and numerous stakeholders - both public sector regulators and law enforcement entities and the varied industries within the 
private sector - currently present in the primary products space. We have added two additional types of counterfeiting that have been demonstrated within the New Zealand primary products context. These include 'IP Misuse' where illegitimate packaging or labelling is reproduced to look like the legitimate product, and 'Non-compliance' where goods that do not comply with regulator requirements are knowingly produced or sold.

Figure 1. New Zealand Primary Product Counterfeiting Typology ${ }^{17}$

\begin{tabular}{|c|l|c|c|c|c|c|}
\hline \multicolumn{2}{|l|}{ Types of Counterfeiting } & Wine & Zespri & $\begin{array}{l}\text { Apple } \\
\text { and Pear }\end{array}$ & Honey & Dairy \\
\hline Counterfeit & $\begin{array}{l}\text { All elements of a product are fraudulently } \\
\text { replicated, including packaging }\end{array}$ & $\bullet$ & $\bullet$ & & $\bullet$ & $\bullet$ \\
\hline Adulterate & $\begin{array}{l}\text { One or more elements of the legitimate product } \\
\text { is substituted or fraudulent }\end{array}$ & $\bullet$ & & $\bullet$ & $\bullet$ & $\bullet$ \\
\hline Tamper & $\begin{array}{l}\text { Products/packaging which are legitimate but } \\
\text { have been used in a fraudulent way }\end{array}$ & $\bullet$ & $\bullet$ & $\bullet$ & $\bullet$ & $\bullet$ \\
\hline Simulated & $\begin{array}{l}\text { Unauthorised/copied product is designed to } \\
\text { look like the real product }\end{array}$ & $\bullet$ & & $\bullet$ & $\bullet$ & $\bullet$ \\
\hline Over-Run & $\begin{array}{l}\text { Legitimate product is made in excess of pro- } \\
\text { duction agreements }\end{array}$ & & & & & \\
\hline Theft & $\begin{array}{l}\text { Product that is stolen and passed off as legiti- } \\
\text { mately procured }\end{array}$ & & $\bullet$ & & & \\
\hline Diversion & $\begin{array}{l}\text { Sale or distribution of legitimate product } \\
\text { outside of intended markets }\end{array}$ & & & & & \\
\hline $\begin{array}{c}\text { IP Misuse } \\
\text { tllegitimate packaging/labelling is reproduced } \\
\text { to look like legitimate product }\end{array}$ & & $\bullet$ & $\bullet$ & & $\bullet$ \\
\hline $\begin{array}{l}\text { Non-com- } \\
\text { pliance }\end{array}$ & $\begin{array}{l}\text { Goods that do not comply with regulator re- } \\
\text { quirements are knowingly produced and sold. }\end{array}$ & $\bullet$ & $\bullet$ & & & \\
\hline
\end{tabular}

Spink suggests that "counterfeiting policymaking and priority setting", in this area, "can be supported by reviewing case studies and general assessments of the issues." 18 Spink et al acknowledge the broad use of the term (as seen in the WTO definition) as well as its use in the specific infringement of intellectual property (IP) rights regarding trademarks and patents. They also provide clarity of definitions by establishing a separation between 'deceptive-counterfeit' products and 'non-deceptive' counterfeit products. The former are those presented in the marketplace as being genuine with the explicit intent to deceive the purchaser, and the latter are often acknowledged as counterfeit or imitation (often in the form of apparel or other types of luxury items) with no intention to deceive the purchaser, rather simply breaching IP and trademark rights. ${ }^{19}$ The examples identified within the New Zealand primary products context sit largely within the 'deceptive-counterfeit' definition. The following five case studies provide examples 
of recent counterfeiting activity found within the primary industry, in order to clearly understand the specific definitions and types of counterfeiting as they might apply to the production of food.

\section{New Zealand Wine}

New Zealand wine has developed into a high-end NZ $\$ 1.75$ billion industry in less than 50 years. ${ }^{20}$ Recent occurrences such as substituting adulterated wine, misrepresenting product, falsifying export applications, and mislabelling of wine both domestically and in Europe are examples of fraudulent activities within the industry that map with the counterfeiting typology. ${ }^{21}$ New Zealand wine is valued per litre the second highest in the world - behind France - and the rise of counterfeiting has increased thanks to elements of the industry reaching "super-premium" brand status very quickly.

In 2017, MPI instigated criminal proceedings against office holders of a North Canterbury producer in a counterfeiting case involving an estimated "tens of thousands of bottles of New Zealand wines." 22 According to public reports, the 'Simulated' wine had been exported to the United Kingdom (UK), Japan, Fiji, Thailand, and Australia. MPI subsequently charged the company with "making a false statement about the vintage and area of origin of wine" and "exporting wine that did not comply with...eligibility requirements." ${ }^{23}$ The following year, MPI prosecuted a prominent Marlborough wine company for not disclosing "the illegal addition of sugar to post-fermentation wine destined for Europe." ${ }^{24}$ Industry data indicates the external counterfeit threat to the New Zealand wine industry mainly lies in Europe. For example, a 2016 bottle of counterfeit Sauvignon Blanc was procured in Europe, and while the label had the 'Kiwi' emblem and the word "Marlborough", it did not show the name of any winery. ${ }^{25}$

New Zealand Wine, an organisation comprising 850 growers and 700 winery members, views the illicit counterfeit production of wine as opportunist rather than the result of organised crime, although "this situation could change in the future."26 This is already being seen with the leaking of a French Foreign Trade Advisory Board report showing the depth of the problem in China; "for every real bottle of French wine in China, there is at least one counterfeit bottle, and the situation is only getting worse." ${ }^{27}$ A 2016 report also outlined the extent of international wine counterfeiting and the case of Zhen Wang Huang, more commonly known by his Indonesian name Ruby Kurniawan. In that same year, FBI agents raided Kurniawan's home in Los Angeles, and discovered stock-piled empty bottles and old corks, labels "bundled up like currency," and recipes for faking French wine from the Bordeaux region.

New Zealand wine regions are determined to protect their brands, however there is no industry-wide understanding of counterfeiting. ${ }^{28}$ New Zealand Wine views counterfeiting as a 'risk management' issue, and although it represents a considerable proportion of producers, the body remains of the view that any response to counterfeiting 
is the responsibility of individual members or regional associations. ${ }^{29}$ While business supply chain applications such as traceability, country of origin, geographical indications and regulations are appropriate as part of the trade facilitation process, they have little effect on protecting the wine industry from counterfeiting, let alone aiding proactive investigations. Industry representatives acknowledge that wine is indeed vulnerable to counterfeiting and fraud, and a failure to implement a bespoke counter or anti-counterfeiting strategy could heavily impact on brand reputation. Despite recent prosecutions, the local wine industry is still to pursue such an approach beyond latent acknowledgement of a clear information gap. ${ }^{30}$

\section{Zespri}

It is known that Zespri kiwifruit is counterfeited in multiple overseas markets. While 'Theft' counterfeiting of exported kiwifruit in China is well known, ${ }^{31}$ the company has also experienced cases where Chinese-sourced product with actual 'Zespri labels' known as "combo infringing" - has been identified in markets in Europe. ${ }^{32}$ Zespri refer to counterfeiting within their industry as "exact copy counterfeiting," which has less to do with imposter fruit, rather the 'mislabelling' of non-Zespri product with copied trademark labels and containers. According to the industry, counterfeiting varies from small scale false labelling to runs of "almost six million labels having being seized" as recently as 2017.33 This type of 'trademark breach' counterfeiting falls into the 'Tamper' and 'IP Misuse' categories. Despite enforcement actions, illicit labelling production lines emerge as quickly as they are closed down. ${ }^{34}$ The 'Theft' of plant varieties in China, Europe and New Zealand also exemplify another counterfeiting vulnerability for the industry. Prior to 2013, kiwifruit plants were stolen in China after Zespri had conducted 'trials' and later, these stolen plants were found to be growing in large quantities, causing biosecurity and legal issues in both countries. ${ }^{35}$ The theft of plant varieties is a major dilemma for Zespri as the opportunity for offshore prosecution is limited. Zespri utilise local investigators and legal firms for these enforcement actions. ${ }^{36}$

In reputational terms, Zespri sees the damage of counterfeiting as a "slow burn"; an issue that does need to be responded to but is not, as yet, critical. ${ }^{37}$ Such counterfeiting is not seen as coordinated or syndicated, but like the wine industry, more opportunistic. This notwithstanding, there has been a "significant growth of trademark infringing packaging, labels and holograms" during interventions worldwide, and this is being driven largely by organised crime. ${ }^{38}$ Zespri is expected to produce NZ\$2.42 billion worth of exports in 2019. As a result, Zespri officials see the counterfeiting of primary products as being a broader national issue, in that it is no longer a "Zespri product brand reputation issue in isolation", rather a 'New Zealand Inc' reputation threat "where counterfeiting is really going to start impacting" in a much wider sense. ${ }^{39}$ 


\section{New Zealand Apples and Pears}

According to online data sources New Zealand apples and pears' export values in 2018 were NZ $\$ 745$ million and were expected to reach the NZ $\$ 1$ billion mark by $2023 .{ }^{40}$ Export markets for the industry are evenly divided between the traditional markets of North America and Europe and those emerging in Asia and the Middle East. ${ }^{41}$ According to its industry body, New Zealand Apples and Pears, counterfeiting of its products has occurred in European markets since the 1980s. ${ }^{42}$ Back then, the method of counterfeiting was relatively basic; purchase a pallet of boxes containing New Zealand apples, sell the New Zealand apples, then repeatedly refill the boxes with cheaper Argentine or Chilean fruit and sell at premium prices. ${ }^{43}$ During the early 1990s the industry introduced what was then an innovative anti-counterfeiting initiative. Like Zespri, Price Look Up (PLU)-code stickers were applied to each piece of fruit in an attempt to show authenticity, and the labels reduced counterfeiting, but did not solve the problem, as the stickers themselves could be counterfeited ('Tampered'). ${ }^{44}$ New Zealand exports $30 \%$ of its total pip fruit harvest to China. Asian pip fruit counterfeiters follow a similar modus operandi; selling cheaper local or imported apples as New Zealand product because the brand command higher prices. ${ }^{45}$ Similar forms of counterfeiting continue today in international markets with fruit purchased from wholesalers and transferred into New Zealand apple brand boxes, or more often, cartons produced offshore ('IP Misuse'). ${ }^{46}$ In addition to 'Simulated' cartons, the introduction of 'new' varieties not grown in New Zealand is an additional form of 'Counterfeit' activity identified within the industry. ${ }^{47}$ Opportunities for further illicit enterprise occur when growers supply product to the wholesale market directly. 'In country' agreements with importers now provide a better control of the supply chain, however, with advanced technology it is now possible to store fruit for much longer periods. This provides the opportunity for either northern or southern hemisphere countries to supply markets with 'Adulterated' product disguised as New Zealand country of origin. ${ }^{48}$ New Zealand Apples and Pears agree that although counterfeiting has a detrimental effect on the wider primary industries, its primary concern is centred on the phytosanitary quality of the fruit. It is the ultra-low residue levels, combined with good biosecurity practices and relative absence of pests and diseases that gives New Zealand product its premium status. Counterfeit fruit with high residues not found in New Zealand - 'Simulated' counterfeiting - could at the same time pose a potential serious health threat and reputational risk for the industry. ${ }^{49}$ New Zealand Apples and Pears believes "the possibility does exist," for nonstate organised crime to exploit supply chain vulnerabilities that potentially would have a detrimental economic impact upon the wider industry. ${ }^{50}$ As is the case with the wine industry, individual pip fruit businesses or companies manage counterfeiting issues themselves. To this end the industry is unable to provide an estimate of financial losses incurred through counterfeiting. However, unlike New Zealand Wine and Zespri, New Zealand Apples and Pears does assess counterfeiting as an organised crime activity. ${ }^{51}$ 
This notwithstanding, and despite instances of counterfeiting in recent years, the industry claims it has not suffered significantly from such activity. ${ }^{52}$

\section{Mānuka Honey}

A combination of five attributes, (four chemical and one DNA marker) are used to identify New Zealand Mānuka honey from other types, and while more than 15 floral types of honey are produced commercially in this country, it is a unique series of therapeutic properties against a number of ailments that supposedly make the Mānuka product such a premium sought-after commodity, and one vulnerable to counterfeit exploitation. ${ }^{53}$ The Unique Mānuka Factor Honey Association (UMF), a trade organisation that represents 109 members, advised that 2,500 tonnes of Mānuka honey was exported in 2016 at a value of NZ $\$ 215$ million, yet up to four times this amount is believed to be sold globally, indicating 'Adulterated', 'Tampered' and/or 'Simulated' counterfeit activity is rampant. ${ }^{54}$ The quality of some Mānuka products was questioned in the UK, in 2014, with reports of Mānuka honey being available in the markets well in excess of official New Zealand export figures. Such media attention placed pressure on New Zealand producers and regulators to define 'Mānuka honey' and to provide "an accurate product-testing standard, amid concerns of quality, counterfeiting and consumer confusion." ${ }^{55}$ Subsequent independent testing found the properties of some of these New Zealand products contained much lower levels of attributes than would be expected of the product, and resulted in 'High Street' department stores, some of whom sold Mānuka honey product at NZ\$480 per kilogram, ultimately withdrawing them from their shelves. ${ }^{56}$

New Zealand exports much of its honey in bulk, under the general category of 'Pure Honey', making the product open to exploitation. This provides counterfeiters with the opportunity to classify honey as Mānuka, or grade it incorrectly, mislabel the honey or blend it with lesser premium grade product. Of further and significant concern to the industry is that "off the shelf" synthetic products when added to some varieties of honey, can chemically transform inferior products to appear as being Mānuka honey ones. An example of this presented itself in June 2019 when a local company and its owner were fined in excess of NZ $\$ 370,000$ for secretly adding synthetic substances to 14 tonnes of its honey so it could be sold at a higher price. The offending took place over a 16-month period beginning in 2016. MPI was only alerted to the activity thanks to a whistle-blower. ${ }^{57}$ However, should this 'Adulterated' counterfeiting technique become common knowledge, there is a real fear that the local Mānuka industry could quite simply cease to exist. The industry also faces additional 'Simulated' counterfeiting challenges with Mānuka plants being grown in Australia and Portugal. Other regions cultivating the plant include China, South America, and the UK. ${ }^{58}$ Mannuka Honey accounted for $68 \%$ of the total honey export revenue of NZ\$314 million in $2016 .{ }^{59}$ The product is currently being counterfeited globally, particularly in Europe where blending operations 
take place without intervention. Although they may not go so far as to identify this most recent prosecution as falling within this category, industry representatives, like New Zealand Apples and Pears, believe that Mānuka honey is being exploited by international organised crime elements operating within major overseas markets. ${ }^{60}$

\section{Dairy}

The importance of the dairy industry to New Zealand is critical. In 2018, its exports were valued at NZ $\$ 16.6$ billion and accounted for approximately $20 \%$ of the country's total goods and services export earnings. ${ }^{61}$ The 'Adulteration' of dairy products, most notably milk, for economic gain is well known, with numerous examples - including New Zealand cases - of deliberate substitution, dilution, unauthorised enhancement and misrepresentation of raw and processed products. ${ }^{62}$ In early August 2008, executives from the New Zealand dairy co-operative, Fonterra, met with their Chinese joint venture partners, Sanlu Group, and were advised of a 'melamine contamination' in infant formula products. ${ }^{63}$ The UN Food and Agriculture Organisation (FAO) reported that the levels of melamine found were as high as 2,560 milligrams per kilogram (mg/ $\mathrm{kg}$ ) in powdered infant formula, whereas the World Health Organisation (WHO) stipulates the "tolerable daily limit" for melamine levels in infant formula is $1 \mathrm{mg} / \mathrm{kg} .{ }^{64} \mathrm{Be}$ tween early August and mid-September 2008, it is estimated that Sanlu produced 904 tonnes of melamine-adulterated milk powder, worth approximately US $\$ 7$ million. ${ }^{65}$ Five weeks after being notified by Sanlu (and two weeks after the end of the Beijing Olympic Games) Fonterra advised the New Zealand Government of the discovery. ${ }^{66}$ Shortly after, the Chinese Government, in response to an urgent communication from New Zealand officials, commenced a recall of Sanlu Group dairy products in China. Further Chinese testing indicated that the milk products of 20 other dairy companies had "excessive traces of melamine" in various products. Testing also found international brand products made in China by "Cadbury, Nestlé and Unilever were also tainted with the substance melamine," making it, at face value, an industry-wide issue which by this time had resulted in the "death of six babies and poisoning of more than 290,000 mostly infants." ${ }^{\prime 7}$ Nevertheless, Sanlu was the first Chinese company identified producing and selling 'Adulterated' infant formula, and was declared bankrupt in December 2008. Fonterra lost its entire investment capital of USD $\$ 153$ million. ${ }^{68}$

In 2012 when the issue of counterfeiting infant formula was raised again by the dairy industry, MPI claimed it had "rigorous standards and programmes that New Zealand companies exporting infant formula and milk powders must meet," but admitted it had no control over counterfeiting. ${ }^{69}$ In 2015, Fonterra invested in an $18.8 \%$ stake of the baby and child food company Beingmate, supposedly China's biggest domestic supplier of milk formula, and the first venture undertaken by the company in China since the Sanlu scandal. ${ }^{70}$ Allegations of tampering of Beingmate milk powder would surface the following year when a Beingmate company dealer, with criminal links, was 
discovered to have procured cheaper quality milk powder, packed it into Beingmate labelled containers and sold the 'Adulterated' product at a higher price. ${ }^{71}$ In 2016, Beingmate reported a financial loss of NZ\$158 million, and in 2018 Fonterra wrote off NZ\$439 million from its initial NZ\$750 million investment. ${ }^{72}$

\section{Conclusion}

Monitoring primary product integrity through the supply chain is complex, time consuming, difficult and expensive. ${ }^{73}$ It becomes increasingly problematic as product moves further away from the country of origin, however, brand reputation still remains significantly important for producers and regulators alike. The objective of this research has been to consider, and illustrate, how counterfeiting activity manifests itself in selected primary export sector industries in New Zealand.

Somewhat akin to corporate victims of cyber intrusions, thefts and hacks, there is reluctance by industry to provide detailed losses from counterfeiting. This may well be explained because some industries hold individual member companies responsible for investigating and resolving their own counterfeiting issues so are less inclined to divulge these details publicly, as much as the fact that no industry is aware of the full scale of the activity, or the impact, upon the sector. ${ }^{74}$ However, our analysis indicates that counterfeiting, by any definition, is impacting upon these industries, and although actual losses have not been disclosed by industry, the on-going risk to New Zealand's reputation as an exporter of premium quality products remains. In 2019, export revenue from the five industries is expected to total NZ $\$ 22.9$ billion, up from NZ $\$ 13.2$ billion only three years earlier. ${ }^{75}$ International trends would also indicate that as New Zealand primary sector growth increases, counterfeiting in its numerous iterations, is also likely to increase.

The effect of counterfeiting activity in the primary product industry can have a detrimental impact at producer (economic), consumer (health), industry and state (reputation) levels - depending on the economic importance of the industry and the size of the state. For New Zealand, the potential impact of counterfeit-related failures within the industry could be catastrophic. Understandably, since the Sanlu melamine incident in 2008, New Zealand and international media regularly scan the primary industries export sector for similar instances of failure. The result has been further, and ongoing, public scrutiny of New Zealand's primary industry by this country's major trading partners. Our findings show that a simple typology identifies that counterfeiting affects all five primary sector case studies. Primary exporters, who did contribute to the research, are of the opinion that counterfeiting attempts of New Zealand primary products will only increase, with some fearing that the names of iconic goods produced here will in the future become synonymous with product targeted by organised crime. Exporters also agree that counterfeiting is a 'critical threat' to the New Zealand economy, yet it remains of significant concern that a sector earning $80 \%$ of New Zealand's total merchandise export revenues, has no government or industry-coordinated policy 
or infrastructure to address this specific threat. This research has illustrated how counterfeiting can take place at any stage from manufacturing through the supply chain and into markets. Compliance and security systems require constant auditing. It is clear that overseas wholesale and retail markets are the intersecting points where counterfeit and genuine product merge. It is also at this point where the combination of mislabelled and stolen products presents the most serious health and safety risk to consumers, as well as reputational risk to producers. A simple counterfeiting typology will, we hope, assist in consolidating our understanding of the prevalence and risk from this activity and its impact on the New Zealand primary products industry.

1 International Electrotechnical Commission (IEC) and International Organization for Standardization (ISO) (2018). Tackling Counterfeit with IEC and ISO Standards. Geneva: ISO, p.2.

2 Ministry for Primary Industries (2019). Situation and Outlook for Primary Industries June 2019.

Wellington: New Zealand Government, p.4 and p.62.

3 Organisation for Economic Co-operation and Development (OECD) and European Union Intellectual Property Office (EUIPO) (2019). Trends in Trade in Counterfeit and Pirated Goods, Illicit Trade. Paris: OECD Publishing, p.13.

4 Fox, A. (2012). "Counterfeit Infant Formula Threat," Waikato Times, 17 March, 2012. Available at: http://www.stuff.co.nz/waikato-times/7946980/Counterfeit-infant-formula-threat (accessed 12 May 2019).

5 Ibid.

6 See Bhattacharyya, G. (2005). Traffik: The Illicit Movement of People and Things. London: Pluto Press; Cesareo, L. (2016). Counterfeiting and Piracy: A Comprehensive Literature Review. New York: Springer; Chaudhry, P. \& Zimmerman, A. (2009). The Economics of Counterfeit Trade: Governments, Consumers, Pirates and Intellectual Property Rights. Berlin: Springer-Verlag; Dupont, A. (2006).

Transnational Security. In Ayson, R. \& Ball, D. (Eds), Strategy and Security in the Asia-Pacific. Crows Nest: Allen \& Unwin; Yi-Chieh, J. L. (2011). Fake Stuff: China and the Rise of Counterfeit Goods. New York: Routledge; Ling Peng, L., Wan, L, C. \& Poon, P.S. (2013). Self-Discrepancy and Consumer Responses to Counterfeit Products. In Chan, T.S. \& Cui, G. (Eds), Multinationals and Global Consumers: Tension, Potential and Competition. Basingstoke: Palgrave Macmillan; Moore, J.C., Spink, J. \& Lipp, M. (2012). "Development and Application of a Database of Food Ingredient Fraud and Economically Motivated Adulteration from 1980 to 2010," Journal of Food Science, Vol.77, No.4, pp.118-126; Staake, T. \& Fleisch, E. (2008). Countering Counterfeit Trade: Illicit Markets, Best-Practice Strategies, and Management Toolbox. Berlin: Springer-Verlag; Williams, P. (2013). "Transnational Organized Crime," in Williams, P.D. (Ed), Security Studies: An Introduction (2nd Edition). Abingdon: Routledge; and Wilson, B. (2008). Swindled: The Dark History of Food Fraud, from Poisoned Candy to Counterfeit Coffee. Princeton: Princeton University Press.

7 World Trade Organisation (2017). Glossary. Available at: https://www.wto.org/english/thewto_e/ minist_e/min96_e/glossary.htm (accessed 20 March 2019).

8 Moore et al (2012), Op. Cit., p.118.

9 Ibid.

10 Spink, J. (2017). "Product fraud and product counterfeiting as a source of terrorist financing," Security Journal, Vol.30, No.2, Macmillan, p.640.

11 Ministry for Business, Innovation and Enterprise (2017). Parallel Importing, Piracy and Counterfeiting. Available at: http://www.mbie.govt.nz/info-services/business/intellectual-property/parallel-importing-in-new-zealand/parallel-importing-and-piracy-and-counterfeiting (accessed 20 March 2019).

12 Discussion with MBIE Corporate Governance and Intellectual Property Policy advisors and authors, 21 June 2019.

13 Moore et al (2012), Op. Cit., p.123.

14 Crimes Act 1961 and Trade Marks Act 2002 
15 Animal Products Act (1999) Section 127; Wine Act (2003) Section 97; and Food Act (2014) Section 227.

16 Spink, J., Moyer, D.C., Hyeonho, P., \& Heinonen, J. (2013). "Defining the types of counterfeiters, counterfeiting, and offender organizations," Crime Science 2013, 2:8, p.1.

17 Spink et al (2013), p.8.

18 Spink, J. (2017). Op. Cit., p.641.

19 Spink et al (2013), Op. Cit., p.3 and 11.

20 Ministry for Primary Industries (2019), Op. Cit., p.38.

21 Earley, M. (2018). "Auckland businesswoman fined over false wine export applications," Stuff, 17 December 2018. Available at: https://www.stuff.co.nz/business/109423857/auckland-businesswoman-fined-over-false-wine-export-applications? $\mathrm{rm}=\mathrm{a}$ (accessed 21 June 2019).

22 Bayer, K. (2017). "Kiwi Wine Company and Directors Accused of Complex Wine Fraud," New Zealand Herald, 3 August 03 2017. Available at: https://www.nzherald.co.nz/business/news/article. cfm?c_id=3\&objectid=11898422 $($ accessed 20 May 2019).

23 Clarkson, D. (2018). "Alleged Canterbury Wine Fraud Company in Liquidation," Stuff, 14 February 2018. Available at: https://www.stuff.co.nz/business/101431427/alleged-canterbury-wine-fraud-company-in-liquidation (accessed 20 May 2019); and Clarkson, D. (2019). "Southern Boundary Wines director pleads guilty to label fraud charges," Stuff, 5 July 2019. Available at: https://www.stuff.co.nz/business/114023665/southern-boundary-wines-director-pleads-guilty-to-label-fraud-charges?cid=app-iPad (accessed 5 July 2019).

24 Rutherford, H. (2018). "Peter Yealands paid out \$23M as Marlborough Lines agree not to sue him," Stuff, 8 December 8 2018. Available at: https://www.stuff.co.nz/business/109441623/peter-yealands-paidout-23m-as-marlborough-lines-agrees-not-to-sue-him (accessed 20 May 2019).

25 Email, industry representative (name withheld) to authors, 11 July 2017.

26 Ibid.

27 Mustacich, S. (2015). "How Big Is China's Counterfeit-Wine Problem? French Report Calls It An Industry," Wine Spectator, 8 October 2015. Available at: https://www.winespectator.com/articles/howbig-is-chinas-counterfeit-wine-problem-french-report-calls-it-an-industry-52194\# (accessed 15 June 2019). Bosker, B. (2016). "A True Crime Documentary About the Con That Shook the World of Wine," The New Yorker, 14 October 2016. Available at: https://www.newyorker.com/culture/culture-desk/atrue-crime-documentary-about-the-con-that-shook-the-world-of-wine (accessed 13 August 2018), and Wallace. B. (2012). “Chateau Sucker," New York, 11 May 2012. Available at: http://nymag.com/news/ features/rudy-kurniawan-wine-fraud-2012-5/ (accessed 13 April 2019).

28 Email, industry representative (name withheld) to authors, 11 July 2017.

29 Ibid.

30 Ibid.

31 The introduction of more resilient kiwifruit varieties has been the saviour of the industry. Such varieties, in particular the HORT16A 'Gold' brand, were attempted to be grown in China, however the experiment failed. This notwithstanding, the 'Gold' plants were stolen from local Zespri growers and Chinese-grown fruit is found in the Chinese market place today. Gray (2017).

32 Combo-infringing also takes the form of fruit that is not Zespri with a Zespri label, as well as frui that is of Zespri origin but without trademarked Zespri labelling. Email, industry representatives (names withheld) to authors, 3 July 2017.

33 Zespri investigations have determined that consumers in non-English speaking countries do not identify with the word 'Zespri' but do identify with the big red ' $Z$ ' (the word Zespri is coloured red) and the 'fan device' (the $180^{\circ}$ view of a sliced kiwifruit) icons associated with its product. Ibid.

34 Email, industry representatives (names withheld) to authors, 3 July 2017.

35 Gray, J. (2015). "Wiser Zespri Eyes Growing Fruit in China," New Zealand Herald, 20 June 2015. Available at: https://www.nzherald.co.nz/business/news/article.cfm?c_id=3\&objectid=11468151 (accessed 18 April 2019).

36 The New Zealand Police, the Intellectual Property Office of New Zealand (IPONZ) and New Zealand Customs Service can investigate and prosecute copyright pirates and trade mark counterfeiters, however, agencies like MBIE's Intellectual Property enforcement teams, do not have jurisdictional responsibility to investigate activities offshore. Discussion with MBIE Corporate Governance and Intellec- 
tual Property Policy advisors and authors, 21 June 2019, and interview transcript, industry representative (name withheld) with authors, 20 June 2017.

37 Zespri are involved in proactively gathering data from surveillance and raids, as well as enforcement teams working with analysts to identify patterns and themes. Local regional staff and distributors also provide timely market information. Email, industry representatives (names withheld) to authors, 3 July 2017.

38 World Customs Organisation (2014). Illicit Trade Report: 2013, pp.61-73, and OECD (2016). Op. Cit., p.11.

39 Interview transcript, industry representative (name withheld) with authors, 20 June 2017.

40 Ministry for Primary Industries (2019), Op. Cit., p.38.

41 Pollard, A. (2017), New Zealand Apples and Pears, News, 17 February 2017. Available at: https:// www.pipfruitnz.co.nz/News_and_Events?cms_584_param_detail=5851 (accessed 20 April 2019).

42 Interview transcript, industry representative with authors, 26 July 2017.

43 Ibid.

44 According to the International Federation for Produce Standards (IFPS), a PLU Code is four or five-digit numbers that appear on small stickers applied to fruit, or any other fresh produce. The number identifies produce based upon various attributes, including "commodity, variety, growing methodology (e.g. organic), and size." Available at: http://www.ifpsglobal.com/Identification/PLU-Codes (accessed 23 January 2019).

45 Vietnam and other new emerging markets is where New Zealand Apples and Pears expect increased counterfeiting activity to take place in the near future. Interview transcript, industry representative with authors, 26 July 2017.

46 One other novel form of counterfeiting is to produce "half branded boxes - one side of the box with one brand and the other side with a different brand." Ibid.

47 Ibid.

48 Ibid.

49 Ibid.

50 The industry has developed relationships with government agencies, particularly MPI, MFAT and New Zealand Trade and Enterprise (NZTE) who can provide direct support if a potential bio-risk or market access crisis were to evolve. Ibid.

51 Ibid.

52 Ibid.

53 See The True Honey Company (2017). Mānuka Honey Science Definition, 20 Aril 2017. Available at: https://www.truehoney.co.nz/en/2017/04/20/the-definition-of-delicious-mpi-releases-its-test-for-manuka-honey/ (accessed 29 April 2019); Huka Honey Hive (2014). The Wonderful World of Bees, New Zealand Honey. Available at: https://www.thewonderfulworldofbees.co.nz/ (accessed 1 September 2018); and MPI (2017). Criteria for identifying Manuka Honey: A summary of the Manuka honey science programme, MPI Technical Paper No: 2017/28. Wellington: MPI, pp.7-8.

54 IEC and ISO (2018). Op. Cit., p.17, and Email, industry representative (name withheld) with authors, 11 August 2017.

55 Usborne, S. (2014). "The Manuka Honey Scandal," The Independent, 1 July 2014. Available at: http://www.independent.co.uk/life-style/food-and-drink/features/the-manuka-honey-scandal-9577344. html (accessed 27 April 2019); and Morrison, T. (2016). "New Zealand Honey Exports Soar 41\% in 2015 to New Record," National Business Review, 1 February 2016. Available at: https://www.nbr.co.nz/article/ nz-honey-exports-soar-41-2015-new-record-b-184226 (accessed 27 April 2019).

56 Stock, R. (2017). "Queen's grocer pulls New Zealand Manuka from shelves," Stuff, 5 February 2017. Available at: http://www.stuff.co.nz/business/industries/89047444/Queens-grocer-pulls-New-Zealand-manuka-honey-from-shelves (accessed 25 May 2019).

57 Flahive, B. \& Rosenberg, M. (2019). "Manuka honey fraud: Evergreen Life Ltd handed \$260,000 fine for adding synthetics to its product," Stuff, 28 June 2019. Available at: http://www.stuff.co.nz/business/farming/112342524/mnuka-honey-fraud-evergreen-life-ltd-handed-260000-fine-for-adding-synthetics-to-its-product?cid=app-iPad (accessed 28 June 2019).

58 Interview transcript, industry representative (name withheld) with authors, 21 June 2017.

59 Ministry for Primary Industries (2019), Op. Cit., p.60. 
60 Anecdotal data suggests that such efforts would offer significant financial gains to counterfeiters "in the vicinity of millions per month," Interview transcript, industry representative (name withheld) with authors, 21 June 2017.

61 Dairy Companies Association of New Zealand (2019). Dairy Farming Industry \& Milk Production History NZ. Available at: https://www.dcanz.com/about-the-nz-dairy-industry/ (accessed 20 May 2019); and Dairy NZ (2019). QuickStats about dairying - New Zealand. Available at: https://www.dairynz. co.nz/media/5791052/quickstats-about-dairying-new-zealand-2019.pdf (accessed 20 May 2019).

62 Cavin, C., Cottenet, G., Blancpain, C., Bessaire, T., Frank, N. \& Zbinden, P. (2016). "Food Adulteration: From Vulnerability Assessment to New Analytical Solutions," Chimia 70 (2016), pp.329-333.; Moore, J.C., Spink, J. \& Lipp, M. (2012). Development and Application of a Database of Food Ingredient Fraud and Economically Motivated Adulteration from 1980 to 2010," Journal of Food Science, Vol.77, No.4, pp.121-124; and IEC and ISO (2018). Op. Cit., p.17.

63 The chemical compound Melamine is a by-product of the coal industry with numerous industrial uses. It contains high levels of nitrogen and when added to diluted milk gives the appearance of normal protein levels. See Mooney, P. (2008). "The Story Behind China's Tainted Milk Scandal," USA News, 9 October 2008. Available at: https:/www.usnews.com/news/world/articles/2008/10/09/the-story-behindchinas-tainted-milk-scandal (accessed 26 June 2019).

64 Food and Agricultural Organization (FAO) of the United Nations (UN) (2008). WHO Expert meeting to review toxicological aspects of melamine and cyanuric acid, 1-4 December 2008. Available at: http://www.fao.org/food/food-safety-quality/a-z-index/melamine/en/ (accessed 23 June 2019).

65 Changbai, X. \& Klein, K.K. (2010). "Melamine in milk products in China: examining the factors that led to deliberate use of the contaminant," Food Policy 35, No.5, p.467.

66 Mooney (2008).

67 According to Xiu and Klein. "Consumption of melamine caused infants to develop kidney stones, which, if left untreated, could cause renal failure and death," Changbai \& Klein (2010), p.463, and Mooney (2008).

68 Changbai \& Klein (2010), p.468.

69 Fox (2012).

70 Tajitsu (2014); and Hutching, G. (2017). "Fonterra Chinese Partner Beingmate's Shares Fall as Asset Sale Imminent," New Zealand Farmer, 13 July 2017. Available at: https://www.stuff.co.nz/business/ farming/94708137/fonterra-chinese-partner-beingmates-shares-fall-as-asset-sale-imminent (accessed 30 June 2019).

71 Business Farming Rural Reporters (2018). "Fonterra and Beingmate - where did it all go sour?" Stuff, 21 March 2018. Available at: https://www.stuff.co.nz/business/farming/102473864/fonterra-andbeingmate--where-did-it-all-go-sour (accessed 19 June 2019).

72 Hutching, G. (2018). "How Fonterra sold Beingmate to shareholders - and got it wrong," Stuff, 26 September 2018. Available at: https://www.stuff.co.nz/business/farming/107382282/how-fonterra-soldbeingmate-to-shareholders--and-got-it-wrong (accessed 19 June 2019).

73 Cavin et al (2016), Op. Cit., p.332.

74 Elements of the French wine industry also claim that the illicit trade of their product is "impossible to quantify with precision." Mustacich (2015).

75 Ministry for Primary Industries (2019), Op. Cit., p.16, 38 and 58. 